Islamiconomic: Jurnal Ekonomi Islam

Volume 11 No. 2 July - December 2020

P-ISSN: 2085-3696; E-ISSN: 2541-4127

Page: 161 - 180

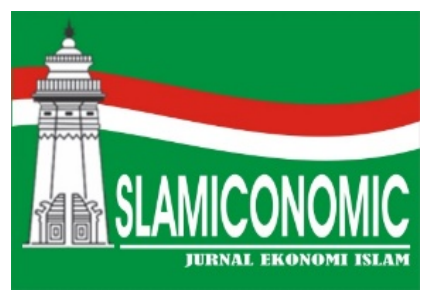

ISLAMICONOMIC: Jurnal Ekonomi Islam

Department of Islamic Economics

Faculty of Islamic Economics and Business

Universitas Islam Negeri Sultan Maulana Hasanuddin Banten

Jalan Jenderal Sudirman No. 30 Serang 42118

BANTEN - INDONESIA

Phone: +62254 200323 || Fax: +62254 200022 || Website: www. journal.islamiconomic.or.id

\title{
COMPARISON OF THE IMPLEMENTATION OF MAQASHID SHARIA IN CERTIFIED SHARIA HOTELS AND UNCERTIFIED SHARIA HOTELS (STUDY ON SHARIA HOTELS IN INDONESIA)
}

\author{
Memed Sueb' ${ }^{1}$ Euis Nurhayati², Indri Yuliafitri ${ }^{3}$ * \\ 123 Universitas Padjadjaran, Bandung, Indonesia \\ *Corresponding author: indri.yuliafitri@unpad.ac.id
}

\begin{tabular}{|c|c|c|}
\hline \multicolumn{3}{|c|}{ Information } \\
\hline \multicolumn{3}{|c|}{ Article History: } \\
\hline Received & & 28.10 .2020 \\
\hline Revised & : & 07.11 .2020 \\
\hline Accepted & : & 22.11 .2020 \\
\hline
\end{tabular}

Keywords: Sharia Hotel, Maqashid Syariah, Islamic Social Reporting

\begin{abstract}
:
The performance of Islamic entities does not only consist of aspects of financial performance (economic performance), but also views from the aspect of sharia as a characteristic that distinguishes it from conventional entities. The purpose of sharia is revealed in the form of maqashid sharia which must be applied in all aspects of life. Therefore, the maqashid sharia approach can be an alternative choice for assessing the performance of a sharia-based entity. In addition, another requirement for Islamic entities is to disclose Islamic Social Reporting (ISR), in which there are 43 items that are characteristic of Islamic entities that must be disclosed in the financial statements of Islamic entities as a form of accountability for Islamic entities. This research uses a qualitative approach by means of case studies based on the interpretive paradigm in order to capture the performance of Islamic hotels using the maqashid sharia approach, and to see whether the elements in Islamic Social Reporting already exist in Islamic hotels. Based on the results of a survey of sharia hotels in Indonesia, both those that have been certified as sharia hotels, hotels that have halal certification for their restaurants, and hotels that claim to be sharia hotels. The conclusion is that certified sharia hotels have been proven to have implemented and maintained sharia values in their hotel operations, although there were some insignificant violations. The implementation of sharia values is not only applied by sharia hotels that have been certified as sharia hotels. The new sharia hotels apply the halal concept, either claiming to be a sharia hotel in the name of the hotel or not mentioning the word sharia in the hotel name. In fact, there were almost perfect implementations in several Islamic hotels that were not yet certified as sharia hotels. It's just that for 2-star hotels and below that claim to be sharia hotels, the implementation of sharia values is only limited by not accepting guests who are not legal spouses, and not providing liquor.
\end{abstract}




\section{A. INTRODUCTION}

Sharia economy is a developing economic system in which the economic activities are built upon Islamic religious values. Since Islam is a comprehensive religion, the Islamic teachings cover all aspects of human life, such as economy, politics, social, culture, education, and so on. Therefore, the main goal of Islamic teachings is rahmatan lil 'alamin (to be a blessing for the universe). As for the government, the welfare of all people is the ultimate goal of development. While, for the company, the welfare of shareholders, stakeholders and the social environment is a goal that must be achieved.

Maqashid sharia is a general goal that must be achieved and applied in life activities. The maqashid sharia approach is starting to become an alternative choice for sharia entities to be implemented in their business activities. This can be seen from the emergence of researches that employ the maqashid sharia approach in reviewing the performance and the corporate governance, especially of those Islamic entities.

The implementation of Islamic entities governance from the maqashid sharia point of view has become the attention of researchers even though it is still relatively limited in number. Among them is Najim Nur Fauziah (2017) who examined the implementation of corporate governance in terms of maqashid sharia at Bank Mandiri Syariah, the results proved that the practice of corporate governance at an independent Islamic bank has implemented Islamic values. In addition, Mohammed et.al., (2008) through their research have made a performance measurement on the maqashid sharia cooperatives in the form of the Sharia Maqasid Index (SMI). Maqashid sharia measured in this study is based on the concept of maqashid sharia described by Muhammad Abu Zahrah (1994) in his book "Ushul Fiqh" which explaining the concept of maqashid sharia more broadly and generally, that there are three purposes for the existence of Islamic sharia, namely: Tahdzib al-Fard (educating individuals), Iqamah al-'Adl (upholding justice) and Jalb al-Maslahah (maintaining benefit).

The development of the sharia economy does not only occur in the banking industry or other financial industries, but also has expanded even to the tourism 
Memed Sueb and others: Comparison of the...

industry. Currently, Indonesia is intensively developing the concept of halal tourism. As a country with the largest Muslim citizens in the world, Indonesia has propitious potential in halal tourism. This is evidenced by Indonesia's success in obtaining the $4^{\text {th }}$ rank in Top Market by Size: Top Muslim Tourism Expenditure, with a nominal value of 9.7 billion USD from 2016 (Pitana \& Gayatri, 2005). This development of halal tourism in Indonesia will certainly have an impact on the development of hotels industry, especially sharia hotels.

Arise of sharia hospitality industry in Indonesia was pioneered by Sofyan Hotel by Riyanto Sofyan in 1992. Originally the hotel was named Menteng Hotel founded by Sofyan Ponda in 1968, and then in 1979 Sofyan Ponda collaborated with Amir Rasyidin Datuk Basa to expand the hotel business into Hotel Menteng I, II and III. However, this collaboration only lasted 4 years, in 1984, Sofyan Ponda took over the Menteng III hotel (changed its name to Sofyan Hotel Cikini) and the Grand Menteng hotel (changed its name to Sofyan Hotel Betawi, now Hotel Sofyan Cut Meutia) (Wikipedia, 2018).

Strengthening its existence in the sharia business, in July 26, 2003, Hotel Sofyan became the first sharia business institution to be certified by the MUI National Sharia Board (DSN). Hotel Sofyan has succeeded in showing the public that employing a sharia brand is not an obstacle to the development of the hotel; instead, this hotel has two benefits at once, namely worldly material and the afterlife benefits.

Since the sharia hotel is a relatively new industry, it is important for the hotel to have more bargaining power in the global industry. Therefore, the authors feel that there is a need for more efforts for sharia hotels to improve its governance quality along with its uniqueness of implementing maqashid sharia in its operations as one of the indicators in implementing the concept of sharia.

The birth of Minister of Tourism and Creative Economy Regulation No.2 of 2014 concerning the guidelines for the implementation of sharia hotel has encouraged the emergence of certified sharia hotels. The granting of this certification refers to Hilal 1 and Hilal 2 as the main characteristics that must be possessed by sharia hotels, in accordance with these regulations.

Given that all human activities basically have to fulfill the objectives of sharia, namely Falah, welfare in the world and the hereafter, through the implementation of 
Islamiconomic: Jurnal Ekonomi Islam

Vol.11 No.2 July - December 2020

maqashid sharia. Thus, managing the sharia hotels should also be in accordance with the maqashid sharia, especially if the hotel is certified as a sharia hotel.

\section{B. LITERATUR REVIEW}

The ultimate goal of maqashid sharia is to achieve maslahah. In this case, it means that maqashid sharia aims to manifest goodness and avoid mudharatan. The Islamic scholars divide maqashid sharia into 3 major groups, namely dharuriyat, hajiyat, tahsiniyat. Dharuriyat is a level of need that must exist, of which there are five main things included into dharuriyat, namely maintaining religion (hifdz ad-Din), guarding the soul (hifdz an-Nafs), maintaining reason (hifdz al'aql), maintaining descent (hifdz an Nasab), as well as maintaining prices (hifzh al maal). Janitra (2017) defines maqashid sharia as the values of Islamic sharia to ensure the achievement of benefit in the world and the hereafter. The importance of maqashid sharia, among others:

1. To understand the achievement of the aims and objectives of Islamic sharia contained in the maqashid sharia.

2. To avoid submission to things in which the law has not yet been decided, there will be law through maqashid sharia.

3. Improving determination and belief in spreading and establishing sharia law in everyday life.

4. Maqashid sharia is the secret to the existence of Islamic sharia in determining laws for various kinds of new problems.

5. Maqashid sharia has a major influence in directing the views and setting the mindset of Islamic economists in general. (Janitra, 2017).

To see the implementation of sharia in an entity, one can follow the formulation of the Islamic scholars, where the most important is dharuriyat, which is something that must exist in order to maintain the integrity of the maslahat of the religion and the world. In this case if something does not exist then the maslahat in the world will not be achieved, and instead lead to destruction.

The dharuriyat case includes the main or basic things that must be present in fulfilling the minimum needs of humans. The dharuriyat case which is later known as maqashid sharia consists of five fundamentals that humans must fulfill as follows: 
Memed Sueb and others: Comparison of the...

1. Preserving religion (hifdz ad-Din)

2. Protecting soul/ life (hifdz an-Nafs)

3. Maintaining intellect (hifdz al-'Aql)

4. Protecting offspring/ nasab (hifdz ad-Nasl)

5. Safeguarding property (hifdz al-Maal)

In order to achieve maslahah, all the activities of Muslims must be able to guarantee the maintenance of these five things, otherwise it will cause damage. Therefore, hotels that claim to be sharia hotels should be able to implement the five concepts above. In 2016, MUI issued the DSN-MUI Fatwa No.108 / DSN-MUI / X / 2016 on Guidelines for the Implementation of Tourism based on Sharia Principles. This fatwa regulates all activities of parties related to sharia tourism, including:

1. Tourists

2. Sharia Travel Bureau (BPWS)

3. Tourism entrepreneurs

4. Sharia Hotels

5. Tour Guide

6. Therapist.

This fatwa defines a sharia hotel business as a provider of accommodation in the form of rooms in a building equipped with food and drink services, entertainment activities and/ or other facilities on a daily basis with the aim of obtaining profits which are carried out according to sharia principles where the formulation of qualifications and classification includes aspects of product, service and management. The contract made between a sharia hotel and tourists is an ijarah contract, which is an agreement for the transfer of use rights (benefits) for a good or service within a certain time with payment or wages. This fatwa states the provisions related to sharia hotels, namely:

1. Sharia hotels may not provide facilities for accessing pornography and immoral acts;

2. Sharia hotels may not provide entertainment facilities that lead to idolatry, immorality, pornography, and/or immoral acts;

3. Food and beverages provided by the hotel must have obtained a halal certificate from the MUI; 
Islamiconomic: Jurnal Ekonomi Islam

Vol.11 No.2 July - December 2020

4. Providing adequate facilities, equipment and means for the implementation of worship, including facilities for washing;

5. Hotel managers and employees/staff must wear clothing in accordance with sharia principles;

6. Sharia hotels are required to have guidelines regarding hotel service procedures in accordance with sharia principles;

7. Sharia hotels are required to use Sharia Financial Institutions services in providing services.

In order to be able to find the difference between certified and uncertified sharia hotels, an explanation of the implementation of maqashid sharia and the elements of governance will be separated between certified and uncertified hotels. Based on the field observations and interviews with informants from the hotel, the implementation of maqashid sharia and the existence of Islamic Social Reporting elements in Islamic hotels are as follows.

\section{METHODOLOGY}

This research used a qualitative approach by means of case studies based on the interpretive paradigm in order to capture the performance of Islamic hotels using the maqashid sharia approach, and to see whether the elements in Islamic Social Reporting already exist in Islamic hotels

\section{RESULT AND ANALYSIS}

\section{The Implementation of Maqashid Sharia in Certified Hotels}

Certified sharia hotels are sharia hotels that have received certificates as sharia hotels from the National Sharia Council (DSN) -MUI. In 2018, there are four sharia certified hotels in Indonesia, namely:

1. Sofyan Hotel Jakarta (SK No.002.59.08/DSN-MUI/III/2018)

2. Syariah Hotel Solo (SK No.008.45.08/DSN-MUI/IX/2016)

3. Grand Permata Hati Hotel Aceh (SK No.016.73.08/DSN-MUI/XII/2018)

4. Permata Hati Hotel Aceh (SK No.015.72.08/DSN-MUI/XII/2018)

Since these hotels have sharia hotel certification, of course these four hotels also have halal certification for their food and beverages. 
Memed Sueb and others: Comparison of the...

\section{The Implementation of Maqashid Sharia in PT Sofyan Hotel Tbk}

PT Sofyan Hotel is the only sharia hotel that has gone public. The development of this company into an open company cannot be separated from the vision it wants to achieve, namely:

"To Be a Leading World Class Hotel"

Along with its missions as follows:

1. Running and developing hotel products and services that are halal and beneficial, provide optimal benefits (best value for the money) and are preferred as the main choice for all.

2. Optimizing the rate of return on investment and a sustainable growth rate.

3. Developing franchise cooperation and hotel management with investors, hotel owners and other hotel operators.

The implementation of the concept of preserving religion (hifdz ad-Din) at Hotel Sofyan is seen in its policies and operations. As a sharia hotel, indeed, Sofyan Hotel has policies that help and facilitate the implementation of worship for both employees and hotel guests such as the availability of prayer equipment, Al-Qur'an and prayer books in every hotel room. The guest bathroom is also equipped with a faucet that makes the guests easy to wash. In addition, there are also clean and tidy prayer rooms and places for ablution in the hotel, making it easier for both employees and guests to carry out worship. In addition, employees must also wear Muslim clothes and greet guests with Islamic greetings. Furthermore, once every two weeks a recitation is also held for employees.

In the implementation of the concept of protecting the soul/ life (hifdz an$N a f s$ ), the hotel management must be able to protect the health and safety of its employee. Therefore, the hotel employees do not need to worry about their health issues as they are enlisted as insurance customers. In addition, the allotment of employees' work hours should also implement the concept of guarding the soul, since as Muslims they also have to protect their bodies so that they do not work beyond their capacity. Even for the female employees, they are not given the night shift, so only male employees work at night. This is of course to maintain security and avoid slander for the hotel employees. 
Islamiconomic: Jurnal Ekonomi Islam Vol.11 No.2 July - December 2020

The implementation of maintaining intellect (hifdz $a l-A q l$ ) in the hotel business, as is done by Hotel Sofyan, includes not providing liquor and other things that can cause people to lose their senses. The Sofyan Hotel business was originally a conventional hotel, and was inseparable from alcoholic drinks and entertainment venues. Since making a hiijrah to become a sharia hotel in 1992, the first thing PT Sofyan Hotel had done is to close its discotheque and bar that used to be the most crowded place in the hotel. The next step taken is to remove alcohol from available food and drinks. This change certainly brings significant impact to the hotel.

The fourth concept in maqashid sharia is to maintain the nafs/ nasab or offspring (hifdz an-nasl). The implementation of this concept is in form of a rule that hotel guests who stay overnight must be with their mahram. It is very important question to ask and convince every guest who comes if they come with their mahram. If the guest cannot prove that they are husband and wife, then they must make a statement letter. In addition, entertainment channels in the hotel are restricted to mostly local and Middle Eastern channels. The hotel also does not provide entertainment facilities that can lead to pornography or porno-action.

The last concept is safeguarding property (hifdz al-maal). The implementation of this concept is by making sure that the treasure gained are obtained in halal and haq manner and used for collective benefit/ goodness. Given that PT Sofyan Hotel Tbk is a company listed on the Indonesia Stock Exchange, which according to the rules must follow/ comply with IFRS that refers to the recording process that does not use the concept of sharia, PT Sofyan Hotel still carried out its activities and reported their activities in accordance with sharia. This is evident from its financial reports that Sofyan hotel still takes Zakat into account. In addition, the bank used by PT Sofyan for its business operations is also a sharia bank.

To maintain its consistency on sharia principles, Sofyan Hotel has a Sharia Supervisory Board, which will ensure that every hotel activity is carried out in accordance with sharia. If there is a violation committed by both employees and management by doing things that are contrary to sharia, they will be given strict sanctions such as dishonorable dismissal in the worst case. 
Memed Sueb and others: Comparison of the...

\section{The Implementation of Maqashid Sharia in the Syariah Hotel Solo}

Syariah Hotel Solo has known as the largest sharia hotel in Indonesia with 378 rooms. This hotel belongs to the Lor in group and was established in the same area as the Lor in hotel. Even so, the Syariah Hotel Management in Solo is consistent with its sharia principles since it has begun to be applied in the hotel symbol using the letter " و", which if interpreted based on the Qur'an means to continue. Therefore, the philosophy of this symbol is that Syariah Hotel Solo will continue to operate in order to achieve its vision, namely:

"To be the first star-rated Sharia hotel in Surakarta and Central Java that is most in demand by consumers and will get significant benefits in the next five years"

The missions of the hotel are as follows:

1. Committed to generating optimal profit for the owner.

2. Fulfill and increase the needs of consumers and hotel voters by providing excellent products and services.

3. Committed to be a hotel with branding that is known by both national and international customers.

As a sharia hotel, Syariah Hotel Solo consistently provides excellent services in accordance with sharia. Although it does not explicitly state the implementation of maqashid sharia, if we look at it from the point of view of maqashid sharia, many hotel activities are in accordance with the maqashid sharia.

The implementation of the concept of preserving religion (hifdz ad-din) is certainly very prominent in sharia-based hotels, including the presence of prayer equipment in hotel rooms and prayer rooms equipped with clean and wellmaintained ablution facilities on almost every floor to make it easier for both employees and hotel guests to pray. Syariah Hotel Solo implements Standard Operating Procedures 5 S (Senyum, Sapa, Salam, Sopan, Santun) in the service to guests. Besides, the hotel is decorated in Middle Eastern nuances and Islamic based principles by avoiding the sculptures or paintings of animals or humans.

To strengthen the existence of Islam in its operational system and the habits of its employees, Syariah Hotel Solo management has a routine agenda on every Friday, such as: 
Islamiconomic: Jurnal Ekonomi Islam

Vol.11 No.2 July - December 2020

1. On Friday the first week, the hajat prayers are performed in congregation following the dhuha prayers.

2. On Friday the second week, the study of Qur'an and Islamic teaching is held for the employees.

3. On Friday the third week, known as "Friday Barakah", the social activities are carried out, such as distributing groceries to Islamic boarding schools or nursing homes.

In addition, every holiday both Eid al-Fitr and Eid al-Adha, the hotel organizes the 'Id prayer in the hotel yard which is open to employees, guests and the community around the hotel. Even the hotel provides free breakfast at that moment.

The implementation of the concept of protecting soul and life (hifdz an-nafs), can be seen from the health insurance provided by the hotel, where all employees are registered in BPJS insurance. In addition, if there are emergency matters, the reimbursement system with a maximum value of 1 month's salary in 1 year is also applied. In order to protect the soul, the division of working hours is also done with 51 formula (five working days, one day off) or 6-1 (six working days, 1 day off, where Saturdays only half a day is included). Therefore, the total working hours of permanent employees is 40 hours/week. And for the female employees, they do not get a night shift, so they go home at the maximum at $10 \mathrm{pm}$ on day shift.

The implementation of the concept of maintaining intellect (hifdz al-aql), can be seen by the unavailability of drinks and foods containing alcohol and inaccessibility to pornographic activities and porno-action. In addition, there are sports activities, such as badminton and futsal, every Friday night, for male employees to maintaining health as well as entertainment/ refreshing and maintaining relationships between employees.

The concept of protecting offspring (hifdz an-nasl) in this hotel is implemented by keeping the hotel form adultery activities. Preventive action is taken from the front office where the officer will ensure that the guests staying overnight is the spouse or mahram. The hotel guests are also not allowed to receive non-mahram guests in the hotel room as the employee will direct them to the hotel lobby. In addition, employees also regularly receive lectures related to how to maintain honor and remain active in carrying out Islamic law. 
Memed Sueb and others: Comparison of the...

The implementation of the concept of safeguarding property (hifdz al-maal) can be seen in the hotel's consistency using Islamic banking to avoid usury. In addition, every room rental payment has included $2 \%$ infaq. The existence of a safe deposit box is also an implementation of the concept of protecting assets. To clean up property, it is in accordance with the concept of safeguarding assets to make sure the assets obtained and used is halal and thoyib to bring maslahah. In addition, to distributing the groceries every Friday on the third week or known as "Friday Barakah, every Eid al-Adha the hotel performs a qurbani ritual by slaughtering 4-5 cows, and distributing it to employees and the community around the hotel. This is a proof of the hotel's commitment to safeguarding property.

To keep every hotel activity in accordance with sharia, the hotel has a Sharia Supervisory Board (DPS), which carries out internal controls. Usually an internal audit is carried out every 3 months.

\section{The Implementation of Maqashid Sharia in the Grand Permata Hati Hotel and Permata Hati Hotel}

Grand Permata Hati Hotel and Permata Hati Hotel are under the same management, namely Permata Hati Group. Thus, the operational system is relatively similar. These hotels have the following visions:

"To Establish a Hotel Based on The Principles of Sharia Hotels and Prioritizing Guest Trust and Satisfaction in Providing Services".

as for the missions of the hotels are as follows:

1. Embedding Islamic values in daily hotel operations.

2. Providing sharia services with friendliness, warmth, and care for every guest who comes.

3. Developing human resources who are faithful, pious, professional and creative.

The hotel which is located in the Veranda of Mecca is supported by an Islamic environment which highly upholds Islamic values in the operational system. Even for employees, the cultivation of Islamic values has started since they were recruited and is still being carried out even though they have become permanent employees. This proves that although there is no written provision that hotel management has 
Islamiconomic: Jurnal Ekonomi Islam

Vol.11 No.2 July - December 2020

implemented maqashid sharia, the actual form of implementation is in the hotel environment.

The implementation of preserving religion (hifdz ad-din) is clearly visible as the hotel rooms provided with prayer tools and Al-Qur'an as well as very clear information on prayer times and Qiblat direction. This certainly makes it easier for hotel guests to carry out prayer services. In the guest bathroom, guests can easily wash themselves. In addition, the position of the toilet is purposely designed to not facing or backwards to the Qiblat.

In addition, there is another special thing that can only be found at Pesona Hati Hotel and Grand Pesona Hati Hotel; a shuttle facility for performing Fajr prayers in congregation at the Baiturrahman Mosque, the Acehnese pride mosque. In the hotel environment, the implementation of preserving religion is carried out in various ways starting from the front office as they provide the clocks that are installed to show prayer times and the front officers who will greet guests with smiles and salam when guests enter the hotel. As for the implementation of worship, the hotel provides a clean and comfortable place for ablution, as well as a clean and comfortable prayer room. In fact, every prayer time are performed in congregational prayers, especially for male employees.

In accordance with its mission to instill Islamic values in everyday life, as well as develop religious, pious, professional and creative resources. Permata Hati Group started from the very beginning of employee recruitment, where one of the requirements to become a hotel employee is to be able to read the Al-Qur'an. And once become an employee, there are provisions to keep the prayers five times a day in congregation, except for employees serving guests. The absence checking during the prayers is also implemented for the employees and become one of the materials for evaluating employee's performance. In addition to praying five times a day, every day the employees pray dhuha before work, read the Al-Qur'an at least 1 sheet per day, and Yasin recitation as additional activity on Friday.

For the implementation of protecting life (hifdz an-nafs), all employees receive life and health insurance protection from the company to guarantee the health of its employees. Apart from that, in terms of spirituality, the company has a policy that all 
Memed Sueb and others: Comparison of the...

employees who receive tips must be collected and reported to HRD. So that there will be no difference in service to all guests.

The implementation of the concept of maintaining intellect (hifdz al-aql) in this hotel is implemented by not providing alcoholic food and drinks, and not providing access to pornography and porno-action. Even if there is a group of hotel guests held a gathering and ask for a night of entertainment such as calling a singer, this is not allowed. Even guests who play cassava (in Aceh it is known as playing batu), are immediately given a warning. In addition, for employees, soft skills training is held to improve the ability of employees to provide the best service for guests. There is also an agenda of dawn safaris for employees which take place in turns while they are not in their schedules. Apart from listening to lectures and dawn prayers in congregation, there are also social activities such as distributing alms.

Even though most of the employees are contract employees, they are still appreciated by the company through Umrah prizes to employees who have worked for at least 7 years, and have a good track record while working. This certainly motivates employees to work well.

The implementation of the concept of protecting offspring (hifdz an nafs) is carried out by ensuring that the female and male guests who come together to stay overnight are legal husband and wife. The prevention process is not only carried out in the front office by asking for ID Card (KTP) or other identity cards to ensure them as a married couple. The prevention has started since guests enter the hotel environment as the hotel securities monitor every guest who enters the hotel environment. If the securities spot any suspicious activity, for example when a male guest goes down by himself to book while his female friend is waiting in the car, they will report this to the general manager, so that the guest will be rejected by the hotel.

On the employee side, especially female employees, the hotel will ask for a letter of approval/permission from their husbands at the beginning of the recruitment considering the hotel working hours are divided by shifts. However, for those whose houses are distant from the hotel, a special policy which conditioned in several ways is prevailed.

The implementation of the concept of safeguarding property (hifdz al-maal) in this hotel is in accordance with its visions and missions as the activity of protecting 
Islamiconomic: Jurnal Ekonomi Islam

Vol.11 No.2 July - December 2020

assets is reflected in the operation of this hotel. At the end of each month, there is a $10 \%$ infaq and $2.5 \%$ zakat on the profits obtained by the company, both from room income, meeting income and bank income. In addition, employee income/salaries are immediately deducted by zakat, which will then be channeled through the Zakat Institution. For bank use, the company uses Islamic banks. In the case of company recording, the hotel uses a cash basis recording system.

\section{The Implementation of Maqashid Sharia on non-Sharia Certified Hotels}

In addition to hotels that have received certification as sharia hotels, there are many hotels that claim to be sharia hotels, both hotels that in all their operating systems try to comply with sharia regulations and hotels that only self-branded themselves as sharia hotels.

The implementation of maqashid sharia in detail can be found in the operational system of sharia hotels, which generally have 3 stars and above, even though the hotel has not received certification as a sharia hotel. However, most of the hotels have received halal certificates for their restaurants. The following hotels are examples of hotels that claim to be sharia hotels:

1. Namira Syariah Pekalongan

2. Syariah Radho Sengkaling

3. Syariah Radho Malang

4. Walan Syariah

5. Arini Hotel Syariah

6. Syariah Umaro Hotel, etc.

There are also many hotels that do not include the word sharia in their names, such as:

1. Hotel Sofyan Inn

2. Hotel Lingga

3. Hotel Grand Dafam Rohan

4. Azizah Hotel, dll

In the discussion regarding the implementation of maqashid sharia in sharia hotels that are not yet certified as sharia hotels, the hotels that will be discussed are sharia hotels with 3 stars and above. It is because based on the results of observations 
Memed Sueb and others: Comparison of the...

for 2-star sharia hotels and below in the form of home stay, the implementation of maqashid sharia is only limited to checking the legality of those couples staying overnight as marriage couple, not providing food and drinks containing alcohol, and not providing access to pornography and porno-action. While for other operations activity are relatively the same as in conventional hotels.

The implementation of maqashid sharia can be found in 3-star hotels and above, even though there are hotels that do not claim to be sharia hotels, only branding the hotels with a halal concept (having halal certificates for their food and drinks).

\section{The Implementation of the Concept of Preserving Religion (Hifdz Ad Din)}

In sharia hotels that have not been certified as sharia hotels, the concept of preserving religion is found in the availability of prayer tools in the hotel guest rooms, as well as the placement of toilets that do not face or turn towards the Qibla. In addition, in several hotels such as the Namira Syariah Pekalongan Hotel, the Grand Dafam Rohan Hotel, and the Radho Sengkaling Syariah Hotel, the Islamic nuance is strongly felt from the moment the guests enter the hotel lobby. At Sharia Radho Sengkaling as soon as we enter the hotel, we will see Middle East TV shows, huge prayer schedules, and greetings from the Front Office. The Islamic climate is also strongly felt at Hotel Namira Syariah Pekalongan where we will find Islamic ornaments used as decorations, and certain areas that are affixed with Islamic hadiths or pearls of wisdom. Even once guests enter the hotel room, they will be greeted with a live Qur'an recitation, which guests can minimize if they feel disturbed.

In addition, these hotels also provide prayer rooms that are clean and well maintained, equipped with ablution places that are also clean and well-maintained. Even at the Grand Dafam Rohan Hotel, we will find a mosque inside the hotel, next to the restaurant.

\section{The Implementation of the Concept Protecting life/Soul (Hifdz An Nafs)}

The implementation of the concept of protecting life is carried out by sharia hotels by registering their employees as insurance participants. In fact, it requires all employees from the highest to the lowest level to pay zakat of $2.5 \%$ on income every 
time they receive a salary, so that the wages consumed are clean from personal zakat obligations. One sharia hotel even has a special policy for female employees who only work until 3 in the afternoon, ensuring that they return home at hours that are relatively safe from crime.

In addition, in order to protect the soul, Islam has forbidden its people to consume food and drink which can cause destruction and damage to human organs. Therefore, sharia hotels, especially those that already have a halal certificate, guarantee that the food and drinks provided are halal guaranteed.

The hotel itself is determined to consistently produce halal products in order to meet consumers' needs and prioritize customers' satisfactions through innovations. To achieve this, the following measures are implemented:

1. Guarantee that all products made are certified by LPPOM MUI.

2. Ensure that all materials used have been approved by LPPOM MUI.

3. Ensure that the production facilities used are free from pork and its derivatives as well as other unclean substances.

4. Train, develop and involve all company stakeholders in order to understand the Halal Assurance System.

5. Provide the necessary resources for the development, implementation and continuous improvement of the Halal Assurance System.

\section{The Implementation of the Concept of Maintaining Intellect (Hifdz Al-AqI)}

The next indicator of maqashid sharia is to maintain intellect. The implementation of maintaining intellect is applied by not providing intoxicating drinks that can damage the mind of the person who consumes them. In addition, the hotels also do not provide facilities that can encourage guests to commit immoral acts. At these sharia hotels, guests will not find facilities that support activities that lead to seclusion, such as a swimming pool that can be used by both men and women altogether, a spa and sauna, a gym area, karaoke facilities, which have the potential to bring non-muhrim male and female guests together. Even if these facilities are provided in the hotels, there will be separation between men and women guests. 
Memed Sueb and others: Comparison of the...

\section{The Implementation of the Concept of Protecting Offspring (Hifdz An-Nasb)}

Furthermore, the implementation of protecting offspring is carried out through a very strict screening process for guests who come to the hotels to ensure that guests who stay overnight are a married couple. In addition, the CCTV in every corner of the hotel is also used to monitor and supervise if there are guests who behave suspiciously.

According to sources from the hotel management, the screening process in ensuring that guests staying overnight are married couples is very strict. This screening process is carried out by looking at their identity cards or family photos. Often times, the hotels also conducted raids on naughty hotel guests.

In addition, the offspring or lineage must also be maintained with supervision and education for the mother as the first school for her children. Therefore, in one of the Islamic hotels being studied, there was a special policy for female employees, in which their number was very minimal and only to do jobs that cannot be done by male employees. In addition, working hours for female employees are limited to 3 in the afternoon, so that those with families still have time to take care of their families.

\section{The Implementation of the Concept of Safeguarding Property (Hifdz Al-Maal)}

It is known that applying sharia principles in a hotel company is imperfect without considering its application on the financial side. In the implementation of safeguarding property, according to our informants at one of the sharia hotels, the concept of protecting property has been carried out by the owner, starting from the construction of hotel buildings and facilities in which the cost to build a hotel building is really from the owner's savings, not from a bank loan containing usury. In addition, the bank that is used to store cash in Islamic hotels is the sharia bank. Even if the hotels are forced to have an account at a conventional bank, this is solely done to facilitate payment access for hotel guests. So conventional bank accounts are only used as intermediaries for payments. Furthermore, when the hotels receive interests from conventional banks, the interests go into the benevolence fund.

Furthermore, as in sharia accounting, the hotels also carry out the obligation to perform financial reporting as a form of responsibility. Besides, the financial statements are only published internally in the company that is owned by individuals. 
Islamiconomic: Jurnal Ekonomi Islam

Vol.11 No.2 July - December 2020

In addition, the company also pays zakat on the company so that the assets it owns are really clean. This is proof that the hotel has implemented the concept of safeguarding assets where assets are obtained through halal and toyyib manner, and used in good ways.

\section{E. CONCLUSION}

The provisional conclusion of this study is based on the results of a survey in several Islamic hotels. It shows that there were different levels of implementation of sharia depending on the scale of the hotel. In relatively small hotels, the application of sharia is still limited to checking that couples who stay overnight are those who are legally married couples, not providing alcoholic drinks, and not providing non-halal food. Whereas in relatively large hotels (at least 3 stars) the application of sharia is more extensive, starting from making sure that couples who stay overnight are proven husband and wife, holding a halal certificate for the food and drinks provided in the hotel, providing the prayer facilities in the room, maintaining the position and layout of hotel facilities that are in accordance with sharia, freeing the hotel financial system from the usury (bank interest), and avoiding details that are violent to sharia law, such as smoking in the hotel area. Therefore, guests really feel the Islamic atmosphere while staying at the hotel.

\section{F. REFERENCES}

Abu Zahrah, Muhammad, (1994).Ushul Fiqh, Jakarta: Pustaka Firdaus,

Abd al-Wahab Khallaf, Ilmu Ushul Al-Fiqh, Kairo: Maktabah al-Da'wah alIslamiyah, 1968.

Asmawi. (2012). Memahami Konsep Maslahah Sebagai Inti Maqasid Al-Syariah. In Workshop Tafsir Asnâf Zakat Kontemporer. Ciputat.

Dusuki, Asyraf Wajdi and Irwani, Abdullah Nurdianawati, 2007. Maqasid alShari'ah, Maslahah and Corporate Social Responsibility, The American Journal of Islamic

Ghofar Shidiq. 2009. Teori Maqashid Al Syariah Dalam Hukum Islam. SULTAN AGUNG VOL XLIV NO. 118 JUNI - AGUSTUS 2009 
Memed Sueb and others: Comparison of the...

Hadi, K., (2012). Implementasi Maqoshid Syariah sebagai Indikator Perusahaan Islami. Jurnal Al-Azhar Indonesia Seri Pranata Sosial, Vol. 1, No. 3

I Gede Pitana, G.Gayatri. (2005). Sosiologi Pariwisata. Yogyakarta: Andi Publisher.

Ika Yunia Fauzia, Abdul Kadir Riyadi. (2015). Prinsip Dasar Ekonomi Islam

Perspektif Maqashid Al Syariah. Sidoarjo: Kencana Prenada Media

Kamali, Muhammad Hashim, (2008.Maqōșid Syariah Made Simple, London: The International Institute of Islamic Thought,

Kamayanti, A. (2016). Metodologi Penelitian Kualitatif Akuntansi Pengantar Religiositas Keilmuan (A.D Mulawarman, ED) (ke Dua). Jakarta: Yayasan Rumah Peneleh.

Marshall, C., and Rossman, G.B. (2016). Instruduction In Designing Qualitative Research (sixth Ed.Thousand Oaks, CA: SAGE Publications Ins.

Mohammed, M. O., Razak, D. A.,\& Taib, F. M., (2008). The Performance Measures of Islamic Banking Based on the Maqasid Framework. Paper of IIUM International Accounting Conference (INTAC IV) held at Putra Jaya Marroiitt, 1-17.

Muhammad Rayhan Janitra. 2017. Hotel Syariah Konsep dan Penerapan. Jakarta: Rajagrafindo Persada.

Qardhawi, Yusuf. 2006. DirÉsÉt fi al-Fiqh Maqashid al-SharÊÑah baina Maqhasid alKulliyah wa Maqashid al-SharÊÑah. Kiaro: Darul Suruq. Raisuni, Ahmad. 20

Salim Darmadi. 2011. Corporate Governance Disclosure in The Annual Report :An Exploratory Study on Indonesia in Islamic Banking

Sandi Rizky Febriadi. (2017). Aplikasi Maqashid Syariah Dalam Bidang Perbankan Syariah. Amwaluna: jurnal Ekonomi dan Keuangan Syariah Vol 1-2 page 231245

Sekaran, U., and Bougie R. 2014. Research Method For Business 6th. Chichester: Jhon Wilery \& Sons Ltd.

Social Science, 24 (1), 25-42 Chapra, M.Umer dan Ahmed, Habib. 2008. Corporate Governance Lembaga Keuangan Syariah. Jakarta. Bumi Aksara.

Sri Perwani, Yayuk, 1992. Teori dan petunjuk praktek housekeeping untuk akademi perhotelan, Jakarta: Gramedia Pustaka Utama. 
Islamiconomic: Jurnal Ekonomi Islam

Vol.11 No.2 July - December 2020

Sugiyono. (2014) Metode Penelitian Kuantitatif Kualitatif dan R\&D. Bandung: Alfabeta

Suriasumantri, J. (2009). Filasafat Ilmu (21 ed). Jakarta: Pustaka Sinar Harapan.

Vanessa, Gaffar, 2007. Customer Relationship Management and Marketing Public Relation. Bandung: Alfabeta 